\title{
Children of Uncertain Fortune: Mixed-Race Jamaicans in Britain and the Atlantic Family, 1733-1833
}

Review Number: 2293

Publish date: Thursday, 15 November, 2018

Author: Daniel Livesay

ISBN: 978-1469634432

Date of Publication: 2018

Price: $£ 41.83$

Pages: 432pp.

Publisher: University of North Carolina Press

Publisher url: https://www.uncpress.org/book/9781469634432/children-of-uncertain-fortune/

Place of Publication: Chapel Hill

Reviewer: Kimberly B. Sherman

Daniel Livesay's first monograph comes at an opportune moment. With the recent release of digital projects such as the University of Glasgow's Runaway Slaves in Britain database, historical attention has focused in on the lives of people of colour in early modern Britain. Children of Uncertain Fortune explores the movement of mixed-race Jamaicans to and from the British Isles during the long 18th century and how they fundamentally challenged ideas about kinship and family membership. As if in response to earlier calls for the wider study of Atlantic families, Livesay's work breathes new life into our understanding of race, kinship and family in the Atlantic world.

Livesay identifies four phases of mixed-race Jamaicans' involvement in Jamaican society and the British Atlantic empire. Beginning in 1733, the first phase was characterised by the Jamaican assembly's attempts to augment the island's white population by privileging the status of mixed-race individuals. After Tacky's Revolt in 1760, Jamaican leadership's attitudes toward free people of colour shifted during a second phase which coincided with the growth of abolitionist movements and new concerns over family formation in Britain and the Atlantic empire. The third phase, occurring in the 1780s, saw the vilification of migrants of colour in Britain and the condemnation of inheritance practices. Finally, the early nineteenth century brought the social and familial exclusion of mixed-race Jamaicans in the British Atlantic world. What began as a society that exhibited fluidity in racial status and kinship in the early 1730s ultimately led to the hardening of differentiation in race and familial membership by the early 19 th century.

In his first chapter ('Inheritance, family, and mixed-race Jamaicans, 1700-61') Livesay recounts how Jamaica's white population limped along for much of its early years due to disease and the threat of warfare. Such an unhealthy tropical climate ultimately turned many potential migrants off. Even so, a small constituency continued to promote the island's better qualities in hopes of building a foundational population of white European colonists. The potential reward of cashing in on the sugar industry initially lured many to the Jamaica, but also kept the island firmly in the hands of an elite and wealthy few. The risks of island life discouraged white women from settling there, thus, the male-dominated population led to stunted white households. This would, in turn, often lead white men to look for sexual partners among the enslaved Africans arriving in the colony, producing a growing population of mixed-race individuals while the white 
population growth stagnated.

The Jamaican assembly approached the situation of free people of colour on a somewhat ad hoc basis, there being no consensus of opinion among white Jamaicans about where mixed-race individuals' place in colonial society. Elite people of colour in Jamaica elevated themselves in colonial society by petitioning the assembly for special privileges that socially and legally placed them at an advantage to other free individuals of colour. Thus, a new social caste emerged that differentiated, not on biology, but on 'considerations of class, kinship, and upbringing' (p. 42). Livesay's analysis of the Jamaican assembly's privilege petition dispensations adds depth by illustrating how proceedings reflected the changing attitudes toward mixed-race Jamaicans over the course of the 18th century. This is excellently contextualized with discussion of larger 18th-century debates about the family, marriage and legitimacy. In the wake of Tacky's Revolt, the Jamaican assembly began imposing caps on inheritance bequests to illegitimate mixed-race offspring and black Jamaicans - signalling a significant change in policy from earlier generations' efforts to bolster colonial society through the dispensation of special privileges to free people of colour.

Even before abolitionism became a widespread movement in the Atlantic world, Jamaican officials knew that slavery posed a variety of risks. In the book's second chapter ('Early abolitionism and mixed-race migration into Britain, 1762-1778'), Livesay discusses how the increasing number of enslaved Africans that arrived annually on the island only served to fan slaveowners' fears of rebellion to flame. Jamaican legislators continued their attempts to promote white settlement and legitimacy through tax exemptions for individuals born to European parents. 'The provision reflected an ongoing interest in promoting marriage and family growth, although now among a more biologically circumscribed group', writes Livesay (p. 93). The lack of educational opportunities in the Caribbean propelled mixed-race Jamaicans to settle in the metropole. What schools did exist often did not accommodate students of mixed heritage and private instruction proved unreliable. Mixed-race Jamaicans found themselves in a variety of locations in Britain, but most settled in England or Scotland with Northern England a favourable compromise between the two.

In Britain, many worried about the long-term effects of slavery on the British Isles themselves. Elite Jamaicans of colour who migrated to the metropole saw little alteration to their status in British society in the years immediately succeeding the inheritance cap, but change was on the wind. Here Livesay points to the Somerset Case, which erupted in 1772, and the mounting concerns over race, family membership, and demography in Britain. The case struck at the heart of a wide range of debates around the issue of slavery, while breaking down the perceived barriers between core and periphery. Livesay argues:

The seeds of abolition were planted by slaveowners themselves, whose obsession with colonial demography and security produced the terms by which reformers would later attack the Middle Passage (p. 91).

Colonial matters were now metropolitan concerns as previous fears surrounding demography and legitimate family units in Jamaica now invaded British communities at home. 
Chapter three ('Lineage and litigation, 1783-1788') discusses how the British Empire's crises of the 1780s shaped discourse about the presence of mixed-race Jamaicans in British households. In the wake of the American Revolution, black Loyalists flooded the metropole. The Crown also initiated formal investigations into the corruption of colonial officials in British India. In addition, the movement to end the transatlantic slave trade gained speed. Livesay illustrates the culmination of these crises in the account of Sarah Cator, a woman of colour from Jamaica who spent time in British India before settling in Britain with her extended family. The legal battle that ensued regarding her inheritance highlighted British perceptions of the 'immoral luxury' in which British colonial officials lived, as well as how 'family idiosyncrasies' and socio-cultural expectations coloured estate litigation (pp. 143, 145). The increasing presence of people of colour from around the globe essentially 'challenged an emerging British sense of whiteness' in the 1780s while adding to the 'growing stigma against blacks in Britain' (pp. 147, 160).

Such changing attitudes from British families toward their mixed-race kin, did little to limit white men's sexual activities and the creation of mixed-race households in Jamaica. White planters also continued to send their offspring to Britain for their education despite the increasingly negative rhetoric surrounding the presence of privileged people of colour arriving in the metropole. 'Competing ideas about race and family coexisted in the 1780s, without any firm resolution' (p. 192). Debates over abolition and colonial corruption raged in the public sphere, while but familial settlements over the issue of incorporating mixed-race individuals into families remained largely private matters.

Chapter four ('Abolition, revolution, and migration, 1788-1793') chronicles how the presence of mixed-race individuals in familial households in Britain remained a stark reminder of the calls for abolition.

Ramifications of the revolution on Saint Domingue in 1791 led to official interest in the migration of people of colour from Jamaica alongside abolitionists' calls to action. In Jamaica, debates about demography and the abolition of the transatlantic slave trade led to additional calls for the support of natural reproduction of individuals already enslaved in Jamaica in order to reduce the need to import large numbers of enslaved Africans each year. Officials cited the economic inefficiencies of the transatlantic slave trade, arguing that ceasing the import of newly enslaved Africans could curtail the potential for rebellion. This also led to an increased interest in enslaved motherhood and the reproductive capacity of enslaved black women to create a self-perpetuating enslaved population. Here Livesay goes into depth discussing what could be seen as inconsistencies in the actions of white men concerning their mixed-race children and the abolitionist movement. Hercules Ross, for instance, fathered mixed-race offspring whom he sent to Britain for their education while becoming an outspoken supporter of the abolition of the transatlantic slave trade. Men like Ross, argues Livesay, ensured that their mixed-race children were supported while also engaging in abolitionist debates 'because they could easily separate family obligations from ideological determinations' (p. 247).

Chapter five ('Tales of two families, 1793-1800') continues the discussion of familial litigation involving people of colour. Litigation and estate settlements, Livesay says, were facts of life in the British Atlantic World and represented 'a high degree of metropolitan assimilation.' In fact, 'there was nothing so quintessentially British in the long eighteenth century as taking a rival heir to court' (p. 249). Settling family legacies became even more complex when white men returned to Britain and created legitimate families. This did not mean, however, that families no longer accepted mixed-race kin into their households, but it complicated migrants of colour's ability to both 'minimize their African ancestry while proving the usefulness of their kinship' (p. 300). Here Livesay draws on the 18th century's popular press, particularly sentimental novels, to illustrate how the public latched onto the implications of mixed-race migration and integration among British families. While race remained one aspect of the discourse surrounding attitudes toward mixed-race Jamaicans in British society, family organisation and inheritance remained pertinent to debates.

Chapter six ('Imperial pressures, 1800-1812') turns to the fourth, and final, phase of Livesay's study culminating in formal and institutionalized measures to exclude Jamaicans of colour from British families 
and society. The ramifications of the revolution on Saint Domingue in 1791 led to the prohibition of people of colour from gaining the position of an officer within the East India Company. As 'extended networks became less personal', persons of colour began camouflaging their heritage in order to advance their lot in society (p. 304). Public, official oppression for people of colour obscured the private arrangements made for their advancement in British society, while definitions of kinship simultaneously became more restrictive.

Migration to the metropole continued, primarily because of a lack of jobs and educational opportunities in Jamaica, as well as social prejudices against people of colour. The possibility of improving children's status through a European education still prompted many parents to send their children abroad. At the same time, the practice of sending mixed-race children to Britain caused some anxiety among British relatives who 'worried that by caring for such family members they were condoning the types of relationships now publicly though improper for British households' (p. 307). Opportunities in Jamaica for people of colour seemed to vanish when the Jamaican assembly ceased approving appeals for privileges in 1802. This, however, had little to no effect upon Jamaican migrants of colour going to Europe or wealthy Jamaicans calling on British kin to assist in the education of their children. Wealthy Jamaicans still expected their mixed-race children to successfully assimilate into British society. However, success was not guaranteed and, in the early 19th century, records reveal not only a 'heightened awareness of physical differences,' but 'an active concern that these relatives were of a separate kinship line as well as a greater public reluctance to accept their assimilation' (p. 314).

Livesay's final chapter ('New struggles and old ideas, 1813-1833') focuses on how families were being both made and unmade in the first three decades of the 19th century. 'Families were, and are, highly precarious things', writes Livesay (p. 348). Attitudes regarding race and identity crystallized in those years as Britons shaped their identities around an exclusionary ideology that privileged whiteness. Families increasingly defined membership in more limited terms of kinship, specifically to those who could positively advance family fortunes. British families viewed mixed-race kin as 'financial dead ends' with the potential to be costly legal obstacles for legitimate kin (p. 348). While racial prejudices came to a head in Britain, the metropole still held valuable educational opportunities for migrants of colour, but offered fewer opportunities for the long term.

Simultaneously, concerns over colonial demography continued to plague the Jamaican assembly. Livesay illustrates how, in an attempt to elevate persons of colour in colonial society, the Jamaican assembly reopened petitions for privileges in 1823. Reiterations of earlier attempts at demographic planning led to the promotion of marriage and stable family structures amongst enslaved communities in Jamaica as a way to encourage reproduction of an enslaved black workforce. Elites of colour steadily advanced in colonial society. Livesay argues that the education of migrants of colour in Britain had served to 'confer social legitimacy on a group of people suddenly entrusted with the colony's future' (p. 397). The same cannot be said for migrants of colour in Britain, where 'intensified anxieties about family composition had pushed relatives of color outside the traditional boundaries of kinship by the 1830s' (p. 397). Opportunities for networking and white patronage evaporated, signalling a deterioration in status for mixed-race kin in Atlantic families.

Livesay's work is a fascinating read. Children of Uncertain Fortune rests on a foundation of extensive primary source research, both in Jamaican and British archives. The vignettes presented in each chapter breathe life into the people whom Livesay has uncovered on the pages of manuscripts and volumes of court records. The book will be incredibly helpful to readers of the history of families, race, and law in the Atlantic world.

The author responds: I greatly appreciate Dr. Sherman's extensive and thoughtful commentary on the book. She has provided a terrific outline of its contents, and primed potential readers to see the contributions that (I hope) it makes to the literature.

Source URL:https://reviews.history.ac.uk/review/2293 
Links

[1] https://reviews.history.ac.uk/item/298416 